\title{
Settling Short on Tobacco: Let the Trials Begin
}

\section{Citation}

Brandt, Allan M., and Julius B. Richmond. 1997. Settling Short on Tobacco: Let the Trials Begin. Journal of the American Medical Association 278(12): 1028.

\section{Published Version}

http://dx.doi.org/10.1001/jama.278.12.1028

\section{Permanent link}

http://nrs.harvard.edu/urn-3:HUL.InstRepos:3708470

\section{Terms of Use}

This article was downloaded from Harvard University's DASH repository, and is made available under the terms and conditions applicable to Other Posted Material, as set forth at http:// nrs.harvard.edu/urn-3:HUL.InstRepos:dash.current.terms-of-use\#LAA

\section{Share Your Story}

The Harvard community has made this article openly available.

Please share how this access benefits you. Submit a story.

Accessibility 


\section{Settling Short on Tobacco}

\section{Let the Trials Begin}

IN THE LAST MONTH, since the announcement of a proposed comprehensive tobacco settlement, many critics have raised serious objections. In particular, they have properly focused on the proposed weakening of the Food and Drug Administration's recently acquired authority to regulate nicotine, as well as limitations on future class-action litigation and punitive damages. Little attention, however, has been focused on the potential public health benefits associated with a wide range of antitobacco litigation that inevitably would attract intense media coverage. The settlement of major tobacco suits and the limitations on other antitobacco litigation would mark the decline of intense tobacco media attention that has, over the last quarter-century, transformed the meaning of cigarette use in American society.

Above all else, the proposed settlement would spare the tobacco industry years of devastating publicity. If the attorneys general's cases, as well as others, are litigated, they will bring into the open a vast array of incriminating documents that reveal the industry's complete disregard for the public's health. These documents—some of which have already surfaced-demonstrate that the industry knew about the harms of smoking, knew about its addictive qualities, and manipulated nicotine content, all the while knowingly and aggressively marketing to children and adolescents. The settlement may limit further exposure of the companies' internal documents.

For decades, the tobacco industry has repeatedly denied the harms of smoking. To continue to deny these risks-as ongoing trials would force the industry to do-stretches all credibility and unmasks the hypocrisy of the tobacco companies. To continue to claim that tobacco is not marketed to children, that it is not addictive, and that it does not necessarily cause cancer and other serious disease is an untenable position. It was this recognition that made the denials at the 1994 Waxman hearings, in which tobacco executives claimed that they did not "believe" tobacco was addictive, so newsworthy.

Although it is impossible to put a dollar value on this antitobacco publicity, history has shown that such revelations have had an important impact on public attitudes and practices regarding cigarette smoking. And time has shown that the me-

From the Department of Social Medicine, Harvard Medical School, Boston, Mass.

Reprints: Allan M. Brandt, PhD, Division of Medical Ethics, Department of Social Medicine, Harvard Medical School, 641 Huntington Ave, Boston, MA 02115. dia attention generated by high-profile trials also provides the public with an education about the hazards of tobacco and the industry's duplicity. Public outrage at the greed and deception of the industry provides a powerful incentive for smokers to quit. Even though the companies have until recently prevailed in the courts, in the court of public opinion they have repeatedly lost.

This, perhaps more than any other reason, explains the industry's eagerness to reach a settlement at this time. They want to get tobacco out of the news. Imagine the headlines, multiplied by 40 state suits and hundreds of other class actions. Imagine the coverage on the national networks, the court channels, the news channels, and the newspapers. The American public, attuned to the drama of the courtroom, will follow these trials with rapt attention. Furthermore, the publicity attendant to the trials will help to generate the political will to enact new and even more aggressive public health programs to reduce smoking. The visibility of the trials could well lead to many of the proposed settlement's most important provisions without any major concessions to the industry.

What the industry really dreads is the incessant drumbeat about the health consequences of smoking that will result from suits by the attorneys general of 40 states over the next several years. The tobacco companies' desire for a settlement makes clear how eager they are to avoid the media spotlight. A tobacco company executive recently was quoted as saying that the settlement would "bring to an end the demonization of tobacco." No cases, no news. No news, no public outcry about industry malfeasance. The settlement, in this fundamental respect, is about the relegitimation of a now deviant industry.

The proposed settlement provides funding for antitobacco education and publicity. Public service announcements and antitobacco education may in part help to stem the tide of recent increases in teen smoking. But it is important to remember that perhaps the most powerful and effective antitobacco education is in the history of deception and greed that would be so prominently and publicly revealed through the trials. The proposed settlement would all but silence the public forum of the courts.

Let the trials begin.
Allan M. Brandt, PhD

Julius B. Richmond, MD 